Vol. 1 No. 02 Hal. 07 - 15

\title{
Suatu Tinjauan Tentang Peranan Kepala Sekolah Dalam Meningkatkan Disiplin Kerja Guru
}

\author{
Asnawati Matondang \\ Dosen PNS Kopertis Wilayah I Sumatera Utara DPK UISU \\ asnawatimatondang@fkip.uisu.ac.id
}

\begin{abstract}
ABSTRAK
Artikel ini bertujuan untuk menarik beberapa kesimpulan yaitu : (1) Kepala sekolah selaku pemimpin di lembaga sekolah mempunyai tanggung jawab untuk membina dan mengarahkan guru-guru, (2) Tanggung jawab kepala sekolah pada hakekatnya mencakup dua hal yakni : tanggung jawab selama hidup didunia dan tanggung jawab diakherat kelak, (3) Bahwa kepala sekolah khususnya sebagai pemimpin mempunyai pengaruh yang sangat besar untuk menegakkan atau meningkatkan disiplin terhadap bawahanya, (4) Kepala sekolah berusaha untuk meningkatkan kedisiplinan kepada bawahan, kepada guru-guru yang bertugas disekolahnya, dan (5) Adanya usaha yang dilakukan oleh Kepala Sekolah untuk meningkatkan kedisiplinan bertugas disekolahnya. Dalam suatu organisasi sangat dibutuhkan bawahan yang memiliki disiplin tinggi. Untuk membentuk dan membina disiplin tersebut, ada beberapa faktor yang harus diperhatikan dan merupakan hal yang sangat penting yaitu : (1) motivasi, (2) Pendidikan dan Latihan, (3) Kesejahteraan. Beberapa tipe kepemimpinan yang teridentifikasi antara lain : (1) Tipe Maternalistis, (2) Tipe Paternalistis, (3) Tipe Militaristis, (4) Tipe Otokratis, (5) Tipe Liasser Faire (Biarkan Saja), (6) Tipe populastis, (7) Tipe Administrasi, (8) Tipe Demokratis. Dan Fungsi-fungsi kepemimpinan antara lain adalah : (a) Memandu atau memberikan panduan kepada organisasi, (b) Menuntun, (c) Membimbing, (d) Memotivasi bawahan atau organisasi (e) mengemukakan organsasi (f) Menjalin jaringan-jaringan komunikasi (g) Memimpin pengikut pada sarana yang ingin dicapai sesuai dengan ketentuan waktu dan perencanaan, (h) Pengawasan yang efisien.
\end{abstract}

\section{PENDAHULUAN}

Pembinaan dalam suatu organisasi baik dalam organisasi perusahaan, pemerintah maupun swasta tidak terlepas dari kepemimpinan seorang pemimpin organisasi itu sendiri. Organisasi sekolah yang dipimpin oleh kepala sekolah perlu memperhatikan dan berusaha membina guru-guru agar berdisiplin tinggi, sehingga mereka dengan sungguh-sungguh menjalankan tugasnya. Seorang kepala sekolah pada hakekatnya juga seorang supervisor. Untuk itu harus mengenal sifat guru-guru yang beraneka ragam. Hal ini disebabkan adanya guru yang acuh dan ada yang kurang disiplin, tetapi lebih dari itu ada guru yang suka mengambil muka kepada kepala sekolah. Dalam kehidupan organisasi, seorang pemimpin mempunyai peranan yang sangat penting, dimana perananya dapat dikatakan sangat menentukan dalam usaha pencapaian tujuan yang telah ditetapkan terlebih dahulu. Oleh karena seorang pemimpin mempunyai keterbatasan, maka untuk mencapai tujuan membutuhkan sekelompok orang-orang untuk digerakkan sedemikian rupa sehingga mereka memberikan pengabdian dan sumbangsih kepada organisasi. Kepala sekolah sebagai pemimpin di sekolah dapat memotivasi guru denga berbagai cara. Kepala sekolah mempunyai peranan sebagai penggerak dalam sekolah. Sekolah sebagai lembaga organisasi dipimpin oleh kepala sekolah dan guru-guru sebagai pegawai merupakan anggota dalam organisasi sekolah harus mampu meningkatkan sumber daya manusia dan sumber daya lainnya serta pada dasarnya merupakan penjabaran dari fungsi kepemimpinan sedangkan fungsi kepemimpinan itu sendiri merupakan salah satu peranan pemimpin dalam rangka untuk menggerakkan semua bawahan untuk memberikan pengabdian dalam mencapai tujuan organisasi sesuai dengan kemampuan masing-masing. 
Asnawati Matondang : Suatu Tinjauan Tentang Peranan Kepala Sekolah Dalam Meningkatkan Disiplin Kerja Guru

\section{KERANGKA TEORITIS}

Dalam kehidupan organisasi, seorang pemimpin mempunyai peranan yang sangat penting, dimana perananya dapat dikatakan sangat menentukan dalam usaha pencapaian tujuan yang telah ditetapkan terlebih dahulu. Oleh karena seorang pemimpin mempunyai keterbatasan, maka untuk mencapai tujuan membutuhkan sekelompok orang-orang untuk digerakkan sedemikian rupa sehingga mereka memberikan pengabdian dan sumbangsih kepada organisasi. Kepala sekolah sebagai pemimpin di sekolah dapat memotivasi guru denga berbagai cara. Kepala sekolah mempunyai peranan sebagai penggerak dalam sekolah. Sekolah sebagai lembaga organisasi dipimpin oleh kepala sekolah dan guru-guru sebagai pegawai merupakan anggota dalam organisasi sekolah harus mampu meningkatkan sumber daya manusia dan sumber daya lainnya serta pada dasarnya merupakan penjabaran dari fungsi kepemimpinan sedangkan fungsi kepemimpinan itu sendiri merupakan salah satu peranan pemimpin dalam rangka untuk menggerakkan semua bawahan untuk memberikan pengabdian dalam mencapai tujuan organisasi sesuai dengan kemampuan masing-masing.

\section{Pengertian Kepemimpinan}

Untuk lebih mengetahui tentang kepemimpinan, perlu dipahami terlebih dahulu defenisi kepemimpinan, karena hal tersebut merupakan pikiran pokok dalam memahami arti kepemimpinan. Dari uraian diatas dapat dijelaskan arti dan pemehaman tentang seorang pemimpin, menurut para ahli :

a. Menurut A. Munit : "Kepemimpinan adalah seni untuk mempengaruhi tingkah laku manusia, kemampuan untuk membimbing orang lain" (2002:33)

b. Menurut Purwanto :"Kepemimpinan itu adalah seseorang yang diberikan kesempatan dan tanggung jawab dalam banyak situasi untuk membimbing ke arah pemecahan soal dan mengambil keputusan" (2007: 15)

c. Menurut Djamarah : "Kepemimpinan itu adalah usaha untuk melibatkan orang lain sehingga bersedia menerima pengarahan dari pemimpin dalam mencapai tujuan"(2000:24)

Dari beberapa defenisi kepemimpinan yang telah dikemukakan oleh beberapa ahli diatas, dapat dikatakan bahwa didalam kepemimpinan itu pada umumnya terdapat kesamaan unsur-unsur sebagai berikut :

1. Kemampuan untuk mempengaruhi orang lain, bawahan atau kelompok

2. Kemampuan untuk membimbing atau mengarahkan tingkah laku orang lain atau bawahan

3. Untuk mencapai tujuan

Bila dikaji lebih jauh lagi, maka akan terdapat tiga implikasi yang penting dari defenisi kepemimpinan yaitu :

1. Kepemimpinan harus melibatkan orang lain yaitu bawahan atau pengikut. Dengan kesediaan mereka menerima pengarahan dari pemimpin, maka para anggota kelompok membantu menentukan status pemimpin dan memungkinkan proses kepemimpinan.

2. Kepemimpinan melibatkan distribusi yang tidak merata dari kekuasaan diantara pemimpin dan anggota kelompok

3. Slain secara sah dapat mengarahkan bawahan atau pengikut mereka, pemimpin dapat juga mempunyai pengaruh.

Dalam mengarahkan bawahan, seorang pemimpin harus memiliki kekuasaan yang lebih besar dari para bawahan tersebut, seperti yang disebutkan diatas, bahwa kepemimpinan melibatkan distribusi yang tidak merata dari kekuasaan diantara pemimpin dan anggota kelompok.Konsep kekuasaan amat dekat dengan konsep kepemimpinan. Kekuasaan 
Asnawati Matondang : Suatu Tinjauan Tentang Peranan Kepala Sekolah Dalam Meningkatkan Disiplin Kerja Guru

merupakan sarana bagi pemimpin untuk mempengaruhi perilaku pengikut-pengikutnya. Setiap pemimpin seorang yang diharapkan melaksanakan beberapa jenis-jenis kekuasaan didalam suatu organisasi.

\section{Latar Belakang Sejarah Kepemimpinan}

Kepemimpinan muncul bersamaan dengan adanya peradaban manusia, batasan dan kelebihan dari seseorang akan terlihat pada saat orang tersebut terpilih menjadi seorang pemimpin. Disatu pihak ada manusia yang terbatas kemampuanya untuk memimpin, dan dilain pihak ada yang mempunyai kelebihan/kemampuan untuk memimpin. Kepemimpinan akan menjalin kerjasama dengan para anggotanya dalam mencapai tujuan, dengan tujuan yang sama maka manusia sebagai makhluk sosial akan selalu bersama hidup dan tinggal dalam suatu kepemimpinan yang terorganisir. Oleh karena itu dapat disimpulkan bahwa seorang pemimpin dapat mengatur jalannya proses kepemimpinan dibantu dengan anggota-anggotanya. Dalam hal ini para ahli mengemukakan beberapa teori yang berbeda-beda, tetapi ada dua teori yang menonjol dalam menjelaskan kemunculan pemimpin yaitu :

\section{a. Teori Genetis \\ b. Teori Sosial}

Teori genetis ini mengatakan bahwa pemimpin itu tidak dapat dibuat, akan tetapi lahir jadi pemimpin oleh bakat-bakatnya yang luar biasa sejak lahir. Dalam kondisi yang bagaimanapun, seseorag yang tidak dijadikan menjadikan pemimpin pada saat tertentu ia akan muncul sebagai pemimpin secara filsafat. Pandangan ini tergolong kepada pandangan yang diterministis. Sedangkan teori sosial sebagai lawan dari teori genetis, adalah bahwa pemimpin itu harus disiapkan dan dibentuk bukan terlahirkan saja. Kemudian juga disebutkan bahwa setiap orang bisa menjadi pemimpin apabila diberikan pendidikan dan pengalaman yang cukup. Demikian juga teori ekologis,dimana teori ini muncul akibat kedua teori diatas, tidak seluruhnya mengandung kebenaran. Teori ini mengatakan bahwa seseorang akan sukses menjadi pemimpin bila sejak lahirnya dia telah memiliki bakatbakat kepemimpinan, dan bakat-bakat ini sempat dikembangkan melalui pengalaman dan usaha pendidikan, juga sesuai dengan tuntutan lingkungan.

\subsection{Tipe kepemimpinan Maternalistis}

Pemimpin itu mempunyai sifat, kebiasaan, temperamen, waktu dan kepribadian sendiri yang unik dan khas, sehingga tingkat laku dan gayanya sendiri yang membedakan dirinya dari orang lain. Seorang pemimpin harus dapat memimpin dengan memberikan motivasi, mempengaruhi, mengarahkan dan berkomunikasi dengan bawahan hingga mencapai tingkat-tingkat prestasi yang menurut anggapan mereka sebelumnya tidak mungkin. Sehingga dengan motivasi, arahan, komunikasi yang baik dengan bawahan dapat meningkatkan gairah dan semangat kerja yang lebih tinggi untuk menjadikan hasil kerja yang berkualitas demi keberlangsungan perusahaan yang lebih baik. Kepemimpinan adalah kegiatan untuk mempengaruhi orang-orang agar mereka mau bekerja dengan ikhlas guna mencapai tujuan bersama. Prinsip-prinsip kepemimpinan adalah merupakan petunjukpetunjuk yang harus dipedomani oleh seseorang dalam kepemimpinannya. Oleh karena itu memahami dan mempraktekkan prinsip-prinsip kepemimpinan tersebut adalah merupakan suatu keharusan. Namun demikian, hasil kepemimpinan seseorang tidaklah semata-mata tergantung pada kemahiran menggunakan prinsip-prinsip kepemimpinan saja, melainkan masih banyak faktor lainnya yang mempengaruhi. Maka yang perlu dan penting diperhatikan adalah penilaian keadaan yang tepat, sehingga dapat menentukan tidakantindakan yang tepat pula. 
Asnawati Matondang : Suatu Tinjauan Tentang Peranan Kepala Sekolah Dalam Meningkatkan Disiplin Kerja Guru

Prinsip-prinsip kepemimpinan dapat diterapkan setiap peningkatan kepemimpinan ataupun kesatuan/organisasi. Dengan sendirinya didalam memperaktekkan tingkat pimpinan maupun besarnya kesatuan yang dipimpinnya itu merupakan salah satu faktor yang perlu diperhatikan dari pemimpin yang mempunyai kharisma adalah para Nabi, para Rasul atau pemimpin-pemimpin politik terkemuka dalam sejarah. Wewenang kharismatik tidak diatur oleh kaidah-kaidah, peraturan-peraturan, akan tetapi bersumber pada diri pribadi individu yang bersangkutan. Kharisma akan semakin meningkat sesuai dengan kemampuan individu untuk membuktikan manfaatnya bagi pengikut-pengikutnya. Wewenang ini dapat berkurang apabila ternyata individu yang memilikinya berbuat kesalahan yang merugikan pengikutnya/bawahanya atau para anggota-anggotanya akan berada didalam lingkungannya.

\subsection{Tipe Paternalistis}

Tipe paternalistis yaitu tipe kepemimpinan yang kebapakan dengan sifat-sifat sebagai berikut :
a. Menganggap bawahanya sebagai manusia yang tidak dewasa
b. Bersikap terlalu melindungi
c. Jarang memberi kesempatan kepada bawahanya untuk mengambil keputusan sendiri.
d. Jarang memberikan kesempatan kepada bawahanya untuk mengambil inisiatif, mengembangkan fantasi dan kreativitas.
e. Sering bersikap maha tahu.

Harus diakuibahwa dalam kesempatan tertentu, tipe ini sangat diperlukan. Sedangkan tipe maternalistis mempunyai kemiripan dengan tipe paternalistis, hanya saja tipe maternalistis bersikap over protective dan disertai dengan kasih sayang yang berlebihan.

\subsection{Tipe Militaristis}

Perlu diperhatikan terlebih dahulu bahwa yang dimaksud dengan seorang pemimpin tipe militaristis berbeda dengan seorang pemimpin organisasi militer.

Seorang pemimpin yang bertipe militaristis adalah seorang pemimpin yang memiliki sifatsifat :
a. Dalam menggerakkan bawahan sistem perintah yang lebih sering dipergunakan
b. Menghendaki kepatuhan mutlak dari bawahan
c. Senang kepada formalitas yang berlebih-lebihan
d. Menuntut adanya disiplin yang tinggi dan kaku dari bawahanya
e. Sukar menerima kritikan dari bawahanya
f. Menghemat upaya-upaya untuk berbagai keadaan

\subsection{Tipe Otokratis}

Kepemimpinan otoktratis mendasarkan diri pada kekuasaan yang selalu harus dipatuhi. Pemimpinnya selalu harus berperan tunggal dan berambisi untuk merajai sesuatu. Kebijakan dan perintah ditetapkan tanpa berkonsultasi dengan bawahan. Pemimpin selalu jauh dari para anggotanya dan senantiasa ingin berkuasa mutlak dan merajai keadaan. Sikp dan prinsipnya sangat konservatif dan ketat kaku.

\subsection{Tipe Liasser Faire (Biarkan saja)}

Kepemimpinan Laisser Faire, pemimpin akan meletakkan tanggung jawab pengambilan keputusan sepenuhnya kepada para bawahan. Disini memimpin hanya sedikit atau hampir tidak sama sekali tidak memberikan pengarahan. Para bawahan diberikan kebebasan sepenuhnya. Sudah barang tentu dengan cara ini, maksud pemimpin adalah menganggap 
Asnawati Matondang : Suatu Tinjauan Tentang Peranan Kepala Sekolah Dalam Meningkatkan Disiplin Kerja Guru

para bawahan sudah dewasa dan tahu apa kewajibanya. Dalam cara komunikasi antara bawahan, maupun antara bawahan dengan pimpinannya kurang sekali. Pemimpin hanya sekali saja "turut" bila benar-benar dianggap perlu dan diminta, oleh bawahan untuk berkomunikasi. Akan tetapi sebagai akibatnya maka proses pengambilan keputusan menjadi lambat dan kelompok tidak terbimbing dan terkontrol.

\subsection{Tipe Populastis}

Tipe dari kepemimpinan ini adalah kepemimpinan yang mampu membangun solidaritas, yang menekan kesatuan terhadap penindasan-penindasan dan penguasaan kekuatan asing. Kepemimpinan ini berpegang teguh pada nilai-nilai masyarakat yang tradisionil, lebih banyak dan kurang mempercayai bantuan luar negeri.

\subsection{Tipe Administrasi}

Kepemimpinan adalah kepemimpinan yang mampu menggerakkan dinamika modernisasi dan pembangunan. Dan dengan demikian dapat dibangun sistem administrasi dan birokrasi yang efisien untuk memerintah. Khususnya untuk memerintah memantapkan integritas bangsa dan usaha-usaha pembangunan.

\subsection{Tipe Demokratis}

Kepemimpinan ini adalah kepemimpinan yang mampu menggerakkan efisiensi dan bimbingan kepada para pengikutnya. Terdapatnya koordinasi pekerjaan dari bawahan dengan penekanan rasa tanggung jawab pada diri sendiri dan kerjasama yang baik. Kepemimpinan yang demokratis, menghargai potensi setiap individu. Dapat mengakui keahlian para spesialis dengan bidang masing-masing, mau mendengarkan nasehat dan sugesti bawahan, dan mampu memanfaatkan setiap anggota seefektif mungkin pada saat dan kondisi yang tepat. Kepemimpinan demokratis mempunyai gejala-gejala, sebagai berikut : organisasi dengan segenap bagian-bagianya berjalan lancar walaupun pemipin tersebut tidak berada di kantor, otoritas sepenuhnya didelegasikan ke bawahan dna masingmasing bawahan menyadari tugas serta kewajibannya. Kepemimpinan demokratis menitik beratkan masalah aktivitas, setiap anggota kelompok yang seluruhnya terlibat aktif dalam penentuan sikap pembuatan rencana-rencana, pembuatan disiplin, keputusan dan etika kerja.

\section{FUNGSI KEPEMIMPINAN}

Fungsi merupakan bagian terpenting dari suatu jabatan atau orang tertentu dalam organisasi. Penting atau tidaknya penyusunan struktur jabatan sangat tergantung pada fungsi yang dapat dilaksanakan. Semakin tinggi/pentingnya satu struktur organisasi semakin tinggi pula syarat-syarat yang diperlukan kepada orang-orang yang menduduki jabatan tersebut, demikian pula sebaliknya. Fungsi suatu bagian yang dapat dipergunakan sebagai tolak ukur untuk menentukan kedudukan dan peran seseorang dalam organisasi. Semakin penting dan luas fungsi yang dijalankan seseorang merupakan pertanda bahwa kedudukan tersebut sangat penting pula dalam organisasi, sehingga fungsi dalam suatu organisasi merupakan faktor kelembagaan dan senantiasa terkait pada jabatan tertentu sehingga fungsi tersebut tidak tergantung kepada orang yang menduduki jabatan tersebut, tetapi tergantung pada jabatan yang dipegang atau dilaksanakan. Dalam hal ini jelas bahwa fungsi dalam suatu organisasi oleh orang yang menduduki jabatan atau wewenang yang sedang dipegang, maka orang tersebutlah yang menentukan fungsinya dalam organisasi. Orang yang menjabat pimpinan dapat berganti setiap waktu tetapi fungsi akan tetap sama dalam kedudukan sebagai pimpinan. Fungsi kepemimpinan adalah fungsi yang harus 
Asnawati Matondang : Suatu Tinjauan Tentang Peranan Kepala Sekolah Dalam Meningkatkan Disiplin Kerja Guru

dilaksanakan oleh seorang pemimpin yang sedang memegang jabatan, yaitu sebagai pimpinan pada suatu kantor atau suatu organisasi. Fungsi tersebut dilaksanakanya sehubungan dengan kedudukanya sebagai pemimpin tanpa fungsi tersebut peranan kepemimpinan akan kurang. Fungsi kepemimpinan tersebut dengan sendirinya timbul pada jabatan tersebut. Oleh sebab itulah setiap jabatan yang mempunyai status sebagai pemimpin(kepala), direktur dan lain-lain sebagainya menjalankan fungsi kepemimpinan sesuai dengan jabatan tersebut. Fungsi seorang pemimpin atau fungsi kepemimpinan merupakan bidang tugas yang sangat luas yang meliputi tugas-tugas rutin yang dapat dirumuskan atau tugas-tugas yang timbul secara mendadak atau tugas yang tidak didugaduga. Tugas-tugas pokok kepemimpinan jika diperhatikan mencakup dua hal yaitu : kedalam dan keluar. Kedalam adalah menciptakan "team work" yang terpadu secara efisien dan efektif dengan segala kondisi-kondisi yang diperlukan untuk itu. Keluar merupakan pelaksanaan tugas pokok pencapaian/memberhasilkan tujuan organisasi. Walaupun kedua fungsi tersebut berbeda tetapi tetap saling berhubungan secara integral dan salah satu fungsi, sehingga tidak dapat diabaikan untuk mencapai tujuan fungsi yang lain. Jika salah satu fungsi terganggu akan mengakibatkan, fungsi yang lain turut terganggu, fungsi apapun yang dilaksanakan dalam suatu organisasi hal tersebut akan tetap terkait dengan faktor manusia, karena manusialah yang menyebabkan organisasi itu ada. Oleh sebab itulah fungsi seorang pemimpin melalui kepemimpinannya, tujuan organisasi dan tujuan individu-individu dalam organisasi agar tercapai haruslah mampu menggerakkan segala sumber - sumber yang ada dalam organisasi. Dapat dikatakan bahwa sekarang pemimpin telah mampu melaksanakan fungsi-fungsi kepemimpinan jika pemimpin tersebut telah mampu mempergunakan sumber-sumber yang terdapat dalam organisasi yang dipimpinnya. Tanpa adanya kemampuan menggerakkan sumber-sumber/potensi-potensi yang ada dalam organisasi maka peranan kepemimpinan terlihat kurang nyata dalam kehidupan berorganisasi. Dari defenisi ini memberikan gambaran sederhana tentang fungsi kepemimpinan yang jika dikelompokkan kepemimpinan berfungsi sebagai berikut : (a) Penggerak atau dinamisator sumber daya manusia (b)Penggerak atau dinamisator sumber daya alam (c)Penggerak atau dinamisator saran-saran lain yang disediakan. Ketiga fungsi diatas terlihat dalam batasan penggerak sumber sumber daya manusia dan sumber daya non manusia (material). Penekanan fungsi kepemimpinan tidak dapat digambarkan dengan jelas. Hal ini dapat dikatakan sebab fungsi kepemimpinan tidak terbatas pada fungsi penggerak sumber daya hanyalah salah satu dari berbagai fungsi kepemimpinan. Sebagai luasnya ruang lingkup tugas seorang pemimpin, demikian juga luasnya ruang lingkup kepemimpinan. Fungsi kepemimpinan senantiasa terkait dengan kondisi-kondisi yang selalu ada dalam organisasi dan faktor-faktor yang memungkinkan mempengaruhi organisasi. Oleh sebab itulah pada bagian lain. Kartini Kartono menyatakan bahwa fungsi kepemimpinan adalah sebagai berikut: Memandu, menuntun, membimbing, membangun, , memberi/membangun motivasi-motivasi mengemudikan organisasi, menjalin hubunganhubungan komunikasi yang baik, memberikan supervisi/pengawasan yang efisien dan membawa para pengikutnya kepada sarana yang diinginkan sesuai dengan ketentuanketentuan dan perencanaan. (2000:61). Defenisi diatas memberikan informasi yang lebih luas tentang fungsi kepemimpinan yang tidak terbatas pada fungsi penggerakan sumbersumber organisasi dalam rangka pencapaian tujuan organisasi. Dari defenisi diatas terlihat bahwa fungsi kepemimpinan senantiasa berkaitan dengan faktor yang berada didalam dan diluar organisasi. Jika diuraikan lebih terperinci, maka fungsi kepemimpinan meliputi fungsi-fungsi antara lain :

- Memandu atau memberikan panduan pada organisasi

- Menuntun 
Asnawati Matondang : Suatu Tinjauan Tentang Peranan Kepala Sekolah Dalam Meningkatkan Disiplin Kerja Guru

- Membimbing

- Memotivasi bawahan atau organisasi

- Mengemukakan organisasi

- Menjalin jaringan-jaringan komunikasi

- Memimpin pengikut pada sarana yang ingin dicapai sesuai dengan ketentuan waktu dan perencanaan

- Pengawasan yang efisien

Dari uraian diatas jelas terlihat bahwa fungsi kepemimpinan merupakan bagian yang sangat vital yang memegang peranan sentral dalam organisasi. Dengan melihat fungsi diatas dapat dikataan bahwa fungsi kepemimpinan suatu organisasitidak mungkin dapat mencapai tujuanya karena banyak faktor-faktor yang berkaitan dengan pencapaian tujuan organisasi sangat tergantung pada fungsi kepemimpinan. Oleh sebab itu pemimpin tanpa diikuti fungsi kepemimpinan akan mengalami hambatan dalam usaha mencapai tujuan organisasi. Oleh sebab ituah pemimpin dengan fungsi kepemimpinan merupakan bagian yang sangat penting dalam suatu organisasi.

\section{PEMBAHASAN}

Dalam suatu organisasi sangat dibutuhkan bawahan yang memiliki disiplin tinggi. Untuk membentuk dan membina disiplin tersebut, ada beberapa faktor yang harus diperhatikan dan merupakan hal yang sangat penting. Faktor-faktor penting dalam membentuk dan membina disiplin itu antara lain :

\section{Motivasi}

Yang membedakan orang-orang didalam suatu organisasi bukan hanya kemampuannya saja, tetapi juga didalam kemauan mereka dalam mengerjakan atau motivasi yaitu keperluan-keperluan, dorongan-dorongan atau tekanan dari dalam hati nurani manusia. Motif adalah alasan-alasan maupun jawaban atas pertanyaan mengapa tingkah laku terjadi, dengan demikian harus diperhatikan motif dari orang-orang didalam organisasi, agar mereka dapat digerakkan untuk mencapai tujuan yang diinginkan, disinilah dibutuhkan peranan kepemimpinan dalam usaha memberikan motivasinya.

\section{Pendidikan dan Latihan}

Salah satu Faktor penting dalam membentuk dan membina, menempah disiplin dan moral adalah melalui pendidikan dan latihan. Melalui pendidikan dan latihan orang akan memperoleh kemahiran dan ketrampilan kerja yang akan membuat dirinya yakin atas kemampuan sendiri. Pendidikan dan latihan akan mempengaruhi orang untuk mematuhi atau menaati ketentuan-ketentuan, peraturan-peraturan, mengikuti cara-cara atau teknikteknik mendidik orang untuk membiasakan diri hidup dalam kelompok dan menumbuhkan rasa setia kawan, kerja sama yang erat dan sebagainya. Kepemimpinan dari seseorang pemimpin pasti turut menentukan berhasil tidaknya pembinaan disiplin dan moral suatu organisasi. Masalah kepemimpinan tidak hanya berkenaan dengan intelektual atau kecerdasan dari seorang pemimpin, tetapi yang paling penting adalah berkenaan dengan moral dan wibawa seorang pemimpin, yaitu berkenaan dengan kepribadianya yang menentukan pilihan dan tindakan yang tepat. Jadi yang penting bagi seorang pemimpin didalam kenyataan karyanya serta tingkah lakunya sehari-hari dalam berbuat atau melaksanakan tugas-tugas sebagai bawahan atau sebagai pemimpin tentunya. 
Asnawati Matondang : Suatu Tinjauan Tentang Peranan Kepala Sekolah Dalam Meningkatkan Disiplin Kerja Guru

\section{Kesejahteraan}

Faktor kesejahteraan memiliki pengaruh yang tidak kecil dalam pembinaan disiplin dan moral.Yang dimaksudkan dengan kesejahteraan lahir dan batin dalam arti terpenuhinya kebutuhan minimal, baik yang bersifat material maupun spiritual untuk pribadi dan keluarga.

\section{Hukum (Law Enforcement)}

Faktor hukum merupakan salah satu dari sekian banyak faktor yang mendukung pembinaan disiplin. Hukum berisi serangkaian peraturan atau norma-norma untuk mengatur, menegakkan, dan memelihara disiplin atau kehidupan berorganisasi, agar segala tugas dan kewajiban dapat terlaksana dengan sempurna. Selanjutnya kepemimpinan dalam masyarakat Indonesia harus dilandasi oleh nilai-nilai moral Pancasila. Dengan demikian, untuk meningkatkan disiplin, maka ketauladanan para pemimpinlah yang menjadi panutan para bawahan. Dalam kepemimpinan pancasila terdapat prinsip-prinsip yang utama dan harus dimiliki oleh seorang pemimpin yaitu :

\section{a. Ing ngarso sungtulodo}

Yang berarti bahwa seorang pemimpin harus mampu lewat sikap dan perbuatanya menjadikan dirinya pola anutan dan ikutan orang-orang disekitar/yang dipimpinnya.

b. Ing Madyo mangunkarso

Yang berarti seorang pemimpin harus mampu membangkitkan semangat berswakarsa dan berkreasi pada orang-orang yang dipimpinya.

c. Tut Wuri Handayani

Yang berarti bahwa seorang pemimpin harus mendorong orang-orang yang diasuhnya agar berani berjalan didepan dan sanggup bertanggung jawab (bahan penataran pedoman penghayatandan pengamalan pancasila)

Berdasarkan prinsip utama dari kepemimpinan tersebut maka seorang pemimpin harus bersikap sebagai pengasuh., pendorong, penuntun dan pembimbing usahanya.

Seorang pemimpin mempunyai tanggung jawab yang tidak ringan. Karena tanggung jawab seorang pemimpin mencakup seluruh tanggung jawab didunia yakni kepada atasanya dan tanggung jawab di akhirat kelakm yakni tanggung jawab kepada Allah SWT. Hal ini relevan dengan sebuah hadist yang berarti setiap kami adalah pemimpin dan setiap pemimpin akan ditanya tentang apa-apa yang ia pimpin. (Syeikh Al Mahyiddin).

\section{KESIMPULAN DAN SARAN}

\section{A. Kesimpulan}

Berdasarkan uraian pada bab terdahulu, maka dapat ditarik beberapa kesimpulan :

1. Kepala sekolah selaku pemimpin di lembaga sekolah mempunyai tanggung jawab dan kewajiban untuk membina dan mengarahkan guru-guru

2. Tanggung jawab kepala sekolah pada hakekatnya mencakup dua hal yakni : tanggung jawab selama hidup didunia dan tanggung jawab di akhirat kelak

3. Bahwa kepala sekolah khususnya, khususnya pimpinan mempunyai pengaruh yang sangat besar untuk menegakkan/meningkatkan disiplin terhadap bawahanya.

4. Kepala sekolah berusaha untuk meningkatkan kedisplinan kepada bawahan, kepada guru-guru yang bertugas disekolahnya.

5. Adanya usaha yang dilakukan oleh Kepala Sekolah untuk meningkatkan kedisiplinan bertugas disekolahnya. 
Asnawati Matondang : Suatu Tinjauan Tentang Peranan Kepala Sekolah Dalam Meningkatkan Disiplin Kerja Guru

\section{B. Saran}

Penulis mempunyai beberapa saran sebagai berikut :

1. Kepala sekolah harus lebih meningkatkan peranannya dalam meningkatkan kedisiplinan guru dalam proses belajar mengajar

2. Dilembaga Sekolah harus diciptakan suatu suasana yang harmonis agar pelaksanaan proses belajar mengajar dapat berjalan lancar

3. Guru sebagai tenaga pengajar dan pendidik hendaknya selalu bersikap terbuka dan lapang dada dan bila ada saran dan kritik yang membangun dari kepala sekolah.

4. Guru hendaknya lebih meningkatkan fungsinya dalam meningkatkan proses belajar mengajar dikelas maupun diluar kelas yang berkaitan dengan kepentingan sekolah

5. Kepala sekolah hendaknya tidak hanya menuntut kewajiban guru disekolah tetapi juga Kepala sekolah harus memperhatikan hak-hak guru ataupun kesejahteraan para guru

\section{DAFTAR PUSTAKA}

A. Munir, 2002. Kepemimpinan Kerja. Jakarta : Bina Aksara

Djamarah, Syaiful Bahri, 2000. Guru dan Anak Didik Dalam Interaksi Edukatif. Jakarta

Effendi, 2002. Psykologi Pendidikan. Surabaya: Usaha Nasional.

Indra Fahrudi, 2006. Bagaimana Memimpin Sekolah yang Efektif. Malang Ghalia Indonesia

Kartini Kartono, 2004. Pemimpin dan Kepemimpinan. Jakarta : Rajawali Pers.

Lazarwi, Soewardi, 2001. Kepala Sekolah dan Tanggung Jawabnya. Jakarta : Yayasan Kanisius.

Maxwel John, 2004. Mengembangkan Kepemimpinan. Bandung : Mitra Media

Purwanto, Ngalim, 2007. Administrasi dan Supervisi Pendidikan. Bandung : Remaja Rosda Karya.

Syafaria Tramono, 2003. Kepemimpinan. Yogyakarta: Cahaya Ilmu

Siagian, Sondang P.,2003. Teori dan Praktek Kepemimpinan. Jakarta : Gunung Agung.

Sabri Akhmad, 2005. Strategi Belajar Mengajar dan MicroTeaching. Jakarta : Quantum Teaching.

Suhartini, Piet, 2003. Prinsip dan Teknik Supervisi Pendidikan. Surabaya: Usaha Nasional.

Wahjo Sumidjo, 2005. Kepemimpinan Kepala Sekolah. Jakarta : PT. Raja Gramedia Persada. 